\title{
Evaluasi Kualitas Hidup Pasien Kanker Serviks yang Mendapat Regimen Kemoterapi Cisplatin-Vinkristin-Bleomisin dan Carboplatin-Paklitaksel
}

\section{Quality of Life Evaluation of Cervical Cancer Patients with Delivered Cisplatin-Vincristine-Bleomycin and Carboplatin-Paclitaxel Chemotherapy Regimens}

\author{
Suwendar ${ }^{1 *}$, Achmad Fudholi ${ }^{2}$, Tri Murti Andayani ${ }^{2}$, Herri S. Sastramihardja ${ }^{3}$ \\ 1. Program Program Studi Farmasi, Fakultas Matematika dan Ilmu Pengetahuan Alam, Universitas Islam Bandung \\ 2. Fakultas Farmasi, Universitas Gadjah Mada
}

3. Fakultas Kedokteran, Universitas Padjadjaran

Submitted: 25-03-2019 Revised: 29-05-2019

Accepted: 11-09-2020

Korespondensi : Suwendar : Email : suwendarsuwendar48@gmail.com

\begin{abstract}
ABSTRAK
Kanker serviks merupakan salah satu jenis kanker dengan prevalensi tinggi pada wanita. Kualitas hidup seseorang akan menurun jika menderita kanker serviks. Pada penderita, penurunan kualitas hidup tidak hanya karena faktor penyakit kanker serviks, namun, regimen kemoterapi juga akan mempengaruhi. Tujuan penelitian ini adalah untuk mengevaluasi dampak penggunaan regimen cisplatin-vinkristinbleomisin dan carboplatin-paklitaksel terhadap kualitas hidup pasien. Melalui penelitian ini dapat diketahui bagaimana perbedaan kualitas hidup pasien kanker serviks pada sebelum dan setelah kemoterapi. Selain itu diamati pula apakah terdapat perbedaan dalam dampaknya terhadap kualitas hidup dari kedua regimen tersebut. Penelitian dilakukan menggunakan rancangan cross sectional pada pasien rawat inap. Data diambil secara prospektif dengan observasi lapangan. Pengukuran kualitas hidup dilakukan menggunakan kuesioner EORTC QLQ-C30. Perbedaan nilai domain sebelum dan setelah kemoterapi pada tiap regimen dianalisis dengan paired t-test $(p<0,05)$. Perbedaan kualitas hidup dari kedua regimen dianalisis dengan unpaired t-test $(p<0,05)$. Hasil menunjukkan terdapat kecenderungan peningkatan nilai domain fungsional, penurunan nilai domain gejala dan peningkatan nilai domain status kesehatan global setelah kemoterapi tiga siklus pada kedua regimen, kecuali gejala mual dan muntah serta kehilangan nafsu makan yang menunjukkan kecenderungan peningkatan. Pasien yang mendapatkan regimen cisplatin-vinkristin-bleomisin menunjukkan peningkatan yang bermakna $(p=0,009)$ pada gejala penurunan nafsu makan. Tidak terdapat perbedaan bermakna pada kualitas hidup pasien yang mendapatkan kemoterapi regimen cisplatin-vinkristin-bleomisin dibandingkan terhadap regimen carboplatin-paklitaksel.
\end{abstract}

Kata kunci: kanker serviks; kemoterapi; kualitas hidup; EORTC QLQ-C30

\section{ABSTRACT}

Cervical cancer is one type of cancer with a high prevalence in women. Quality of life of someone with cervical cancer will decrease. Quality of life can also decrease because of chemotherapy regimens. The purpose of this study was to evaluate the impact of cisplatin-vincristine-bleomycin and carboplatinpaclitaxel regimens on the quality of life of patients. Through this research, how the difference in quality of life of patients with cervical cancer before and after chemotherapy could be known. Additionally, the differences impact on the quality of life of the two regimens also were observed. The study was conducted by using cross sectional design in hospitalization patients. Data were taken prospectively by conducting field observations. Measuring the quality of life was done using the EORTC QLQ-C30 questionnaire. Differences of domain values before and after chemotherapy in each regimen were analyzed by paired t-test $(p<0.05)$. Quality of life difference between two regimens were analyzed by unpaired test $(p<0.05)$. The results showed that there was an increasing trend of the value of the functional domain, impairment of symptoms domain and an increase in the value of global health status domain after three cycles of chemotherapy of two regimens, except the symptoms of nausea and vomiting and loss of appetite that showed an increasing trend. Patients who received cisplatin-vincristinebleomycin regimen showed a significant increasing $(p=0.009)$ in decreased of appetite symptom's scores. No significant differences in the quality of life of patients who delivered chemotherapy regimen of cisplatin-vincristine-bleomycin compared to carboplatin-paclitaxel regimen. 
Keywords: cervical cancer; chemotherapy; quality of life; EORTC QLQ-C30

\section{PENDAHULUAN}

Kanker serviks adalah kanker nomor dua yang paling umum pada wanita di seluruh dunia. Diperkirakan 500.000 wanita didiagnosis menderita kanker serviks tiap tahun. Selain itu diperkirakan lebih dari 50\% penderita meninggal karena penyakit ini ${ }^{1}$.

Kualitas hidup seseorang akan menurun jika menderita kanker. Penurunan kualitas hidup pada penderita juga disebabkan oleh kemoterapi. Kemoterapi dapat mengakibatkan perubahan pada status fungsional pasien akibat efek samping yang ditimbulkan. Berdasarkan hasil penelitiaan di RSUP Dr. Sardjito, Yogyakarta, terjadi penurunan kualitas hidup pada pasien berupa peningkatan gejala muntah selama menggunakan cisplatin sebagai monoterapi atau sebagai kombinasi dibandingkan sebelum menjalani kemoterapi ${ }^{2}$. Penelitian di Yunani menunjukkan hasil yang berbeda. Hasil menunjukkan bahwa kemoterapi yang diberikan sebagai bagian dari kemoradiasi tidak berdampak bermakna terhadap kualitas hidup pasien ${ }^{3}$.

Cisplatin-vinkristin-bleomisin (PVB) merupakan regimen yang direkomendasikan oleh Kementrian Kesehatan ${ }^{4}$ Regimen carboplatin-paklitaksel direkomendasikan sebagai terapi kombinasi lini pertama menurut $\mathrm{NCCN}^{5}$. Meskipun kedua regimen tersebut diketahui merupakan regimen yang direkomendasikan oleh beberapa panduan pengobatan kanker, namun dampaknya terhadap kualitas hidup pasien perlu dievaluasi.

Penelitian yang telah dilakukan mengenai dampak terhadap kualitas hidup adalah regimen carboplatin-paklitaksel. Pemberian regimen tersebut pada 12 pasien di Rumah Sakit Sanglah, Denpasar, meningkatkan kualitas hidup pasien secara bermakna6. Selain itu telah dilakukan pula penelitian mengenai kualitas hidup pasien kanker dengan regimen yang terdiri dari bleomisin dan kemoterapi berbasis platinum yaitu bleomisin-oncovin-mitosin-platinum (BOMP) juga di RS Sanglah. Berdasarkan penelitian tersebut regimen BOMP terbukti memperbaiki kualitas hidup pasien ${ }^{7}$.

Kombinasi cisplatin-vinkristinbleomisin dan kombinasi carboplatinpaklitaksel merupakan dua regimen yang sering digunakan dalam terapi pada pasien kanker serviks karena merupakan regimen pilihan $^{4,5}$. Meskipun demikian, sampai saat ini belum ada penelitian yang khusus membandingkan perbedaan kualitas hidup pasien setelah menjalani kemoterapi dengan kedua regimen tersebut. Melalui penelitian ini dapat diketahui bagaimana perbedaan kualitas hidup pasien setelah menjalani kemoterapi dengan dua regimen kombinasi pada sebelum dan setelah kemoterapi selama tiga siklus serta mengetahui perubahan pada masing-masing domain dengan menggunakan kuesioner EORTCQLQ-C30. Selain itu dapat diamati pula apakah terdapat perbedaan dari kedua regimen tersebut dalam dampaknya terhadap kualitas hidup. Dengan demikian dari hasil penelitian ini diharapkan diperoleh data ilmiah yang mendukung pemilihan regimen kemoterapi untuk pasien kanker serviks.

\section{METODE}

Penelitian ini merupakan studi non eksperimental bersifat analitik rancangan cross sectional dengan observasi lapangan. Penelitian dilakukan di RSUP Dr. Hasan Sadikin Bandung. Populasi adalah pasien kanker serviks rawat inap RSUP Dr. Hasan Sadikin Bandung. Ukuran sampel adalah berupa total sample yaitu seluruh pasien kanker serviks rawat inap dari bulan Juni 2015 sampai Maret 2016 yang memenuhi kriteria inklusi. Kriteria inklusi meliputi pasien rawat inap, diagnosis utama kanker serviks dengan atau tanpa penyakit penyerta (comorbid), pasien dengan regimen PVB dan carboplatinpaklitaksel, baik untuk tujuan kuratif, kontrol, paliatif atau dalam bentuk kombinasi dengan terapi lain dan sudah selesai menjalani tiga siklus. Kriteria eksklusi adalah pasien rujukan rumah sakit lain, pasien waktu pulang meninggal dunia dan status pasien "keluar" 
Tabel I. Data Demografi Pasien

\begin{tabular}{lcc}
\hline & $\mathbf{n}$ & $\mathbf{\%}$ \\
\hline Umur dalam tahun & & \\
$\quad<40$ tahun & 11 & 25,6 \\
$\quad 40$ tahun & 32 & 74,4 \\
Tingkat pendidikan & & \\
$\quad$ Lulusan SD & 13 & 30,5 \\
Lulusan SMP & 8 & 18,4 \\
Lulusan SLTA & 21 & 48,8 \\
Sarjana & 1 & 2,3 \\
Regimen & & \\
Cisplatin-vinkristin-bleomisin (PVB) & 32 & 74,4 \\
Carboplatin-paklitaksel & 11 & 25,6 \\
Stadium & & \\
I & 11 & 24,8 \\
II & 24 & 56,4 \\
III & 6 & 14,1 \\
IV & 2 & 4,7 \\
\hline
\end{tabular}

atas permintaan sendiri (APS), sehingga tidak sepenuhnya menjalani perawatan. Jumlah sampel yang diambil adalah total sample dari pasien kanker serviks rawat inap.

Kuesioner EORTC QLQ-C30 (European Organisation for Research and Treatment of Cancer Quality of Life Questionnaire-Core 30) adalah kuesioner yang digunakan untuk pengukuran kualitas hidup pasien kanker. Kuesioner ini terdiri dari 30 pertanyaan yang terbagi menjadi tiga kategori, yaitu: fungsional, gejala dan status kesehatan/kualitas hidup global. Perhitungan nilai kualitas hidup terdiri dari dua tahap yaitu menghitung raw score dan transformasi linear.

Cara interpretasi skor kualitas hidup berdasarkan pengukuran dengan EORTC QLQ-C30 adalah dengan mengevaluasi skor yang diperoleh. Skor minimal dari hasil pengisian kuesioner adalah 0 dan maksimal adalah 100. Skor yang lebih tinggi merepresentasikan level yang lebih baik untuk domain fungsional dan status kesehatan global, sedangkan untuk domain gejala merepresentasikan level yang lebih buruk². Data yang diperoleh dianalisis dengan paired $t$ test $(\mathrm{p}<0,05)$ untuk mengevaluasi apakah ada perubahan yang bermakna antara kondisi setelah mendapatkan terapi dengan sebelum mendapatkan terapi ${ }^{2}$.

\section{HASIL DAN PEMBAHASAN Karakteristik Demografi Pasien}

Dari 110 pasien yang ditemui selama periode penelitian, diperoleh 43 pasien yang memenuhi kriteria inklusi dan tidak termasuk ke dalam kriteria eksklusi. Tabel I memuat data demografi pasien yang dilibatkan dalam penelitian ini. Sebagian besar pasien berada pada kelompok usia 40 tahun ke atas, dengan rata-rata usia $46,3 \pm 9,6$ tahun dan berada pada kisaran 21-61 tahun. Rata-rata kelompok usia pasien mendekati rata-rata usia pasien pada penelitian sejenis di rumah sakit lain, antara lain RS Sanglah, Denpasar (pasien dengan rentang usia 46-55 tahun mencapai 41,7\%) ${ }^{6}$ dan di RS Sardjito, Yogyakarta (rata-rata usia $47,6 \pm 10,5)^{8}$. Sebagian besar pasien berpendidikan di bawah SLTA (48,9\%), dengan demikian masih harus dilakukan pendampingan pada saat pengisian kuesioner. Hasil yang sama juga diperoleh pada penelitian di RS Dr. Sardjito, yaitu pasien dengan pendidikan di bawah SLTA mencapai $63,2 \%^{8}$. Pasien yang mendapatkan regimen 
Evaluasi Kualitas Hidup Pasien Kanker Serviks yang Mendapat Regimen Kemoterapi

Tabel II. Rata-rata Domain Kualitas Hidup Sebelum dan Setelah Kemoterapi

\begin{tabular}{|c|c|c|c|c|c|c|c|c|c|c|}
\hline \multirow{4}{*}{ Domain } & \multicolumn{10}{|c|}{ Regimen } \\
\hline & \multicolumn{5}{|c|}{ Cisplatin-vinkristin-bleomisin (PVB) } & \multicolumn{5}{|c|}{ Carboplatin-paklitaksel } \\
\hline & \multicolumn{2}{|c|}{$\begin{array}{c}\text { Sebelum } \\
\text { kemoterapi }\end{array}$} & \multicolumn{2}{|c|}{$\begin{array}{c}\text { Setelah } \\
\text { kemoterapi }\end{array}$} & \multirow{2}{*}{$\mathbf{P}$} & \multicolumn{2}{|c|}{$\begin{array}{c}\text { Sebelum } \\
\text { kemoterapi }\end{array}$} & \multicolumn{2}{|c|}{$\begin{array}{c}\text { Setelah } \\
\text { kemoterapi }\end{array}$} & \multirow{2}{*}{$\mathbf{P}$} \\
\hline & $\begin{array}{c}\text { Rata- } \\
\text { rata }\end{array}$ & SD & $\begin{array}{l}\text { Rata } \\
\text {-rata }\end{array}$ & SD & & $\begin{array}{c}\text { Rata- } \\
\text { rata }\end{array}$ & SD & $\begin{array}{c}\text { Rata- } \\
\text { rata }\end{array}$ & SD & \\
\hline \multicolumn{11}{|l|}{ Fungsional } \\
\hline Fisik & 69,71 & 21,89 & 80,95 & 18,16 & 0,011 & 77,04 & 26,10 & 80,74 & 22,22 & 0,375 \\
\hline Peran & 72,38 & 32,32 & 86,10 & 19,09 & 0,017 & 83,33 & 33,33 & 87,41 & 21,20 & 0,381 \\
\hline Emosi & 74,29 & 20,35 & 98,57 & 5,89 & 0,000 & 77,78 & 30,33 & 96,30 & 7,35 & $0,047^{*}$ \\
\hline Kognitif & 89,05 & 16,64 & 96,67 & 9,74 & 0,011 & 92,60 & 12,11 & 98,15 & 5,56 & 0,114 \\
\hline Sosial & 74,76 & 19,96 & 79,05 & 18,67 & 0,178 & 90,74 & 14,70 & 94,44 & 11,79 & 0,282 \\
\hline \multicolumn{11}{|l|}{ Gejala } \\
\hline Kelelahan & 33,65 & 27,68 & 11,11 & 15,94 & 0,000 & 23,46 & 30,65 & 9,88 & 11,71 & 0,116 \\
\hline Mual dan & 18,57 & 17,51 & 23,33 & 27,78 & 0,197 & 18,52 & 32,75 & 20,37 & 21,70 & 0,445 \\
\hline \multicolumn{11}{|l|}{ Muntah } \\
\hline Nyeri & 33,33 & 27,78 & 12,86 & 17,66 & 0,000 & 23,46 & 19,20 & 14,81 & 19,44 & 0,178 \\
\hline Sesak Nafas & 20,48 & 27,44 & 5,71 & 12,75 & 0,003 & 7,41 & 16,90 & 0,00 & 0,00 & 0,103 \\
\hline Sulit Tidur & 24,13 & 24,92 & 2,86 & 9,47 & 0,000 & 27,16 & 27,28 & 3,70 & 11,11 & $0,015^{*}$ \\
\hline Penurunan & 23,33 & 22,21 & 37,14 & 25,27 & 0,009 & 16,67 & 18,63 & 22,22 & 16,67 & 0,257 \\
\hline \multicolumn{11}{|l|}{ Nafsu } \\
\hline \multicolumn{11}{|l|}{ Makan } \\
\hline Sembelit & 20,00 & 28,87 & 2,86 & 12,45 & 0,001 & 19,75 & 27,65 & 0,00 & 0,00 & $0,024^{*}$ \\
\hline Diare & 13,81 & 21,57 & 0,95 & 5,63 & 0,001 & 14,81 & 28,19 & 0,00 & 0,00 & 0,067 \\
\hline Kesulitan & 31,11 & 31,17 & 26,67 & 32,14 & 0,279 & 7,41 & 11,11 & 0,00 & 0,00 & $0,031^{*}$ \\
\hline Keuangan & & & & & & & & & & \\
\hline Status & 39,05 & 15,49 & 75,24 & 13,48 & 0,000 & 48,15 & 31,67 & 73,15 & 15,47 & $0,025^{*}$ \\
\hline \multicolumn{11}{|l|}{ Kesehatan / } \\
\hline \multicolumn{11}{|l|}{ Kualitas } \\
\hline Hidup Global & & & & & & & & & & \\
\hline
\end{tabular}

kemoterapi PVB lebih banyak dibandingkan carboplatin-paklitaksel. Data ini sesuai dengan literatur bahwa pasien yang mendapatkan regimen berbasis carboplatin adalah yang tidak dapat menoleransi cisplatin $^{5}$. Tingkat keparahan pasien dikelompokkan menjadi stadium I, II, III dan IV karena terdapat kemiripan pada tata laksana stadium tingkat A dan B. Sebagian besar pasien yang terlibat dalam penelitian ini berada pada stadium II, yaitu $56,4 \%$. Hal ini berbeda dibandingkan dengan kondisi di RS Sanglah Denpasar 6 . Di rumah sakit tersebut sebagian besar pasien yang dilibatkan berada pada stadium IIIB yaitu $58,3 \%$. Hal ini menunjukkan bahwa ada kecenderungan pasien di RSUP Dr. Hasan Sadikin Bandung lebih dini dalam melakukan pemeriksaan sehingga telah terdeteksi sejak stadium awal.

\section{Hasil Pengukuran Kualitas Hidup Pasien}

Tabel II mencantumkan nilai domain yang menggambarkan kualitas hidup pasien sebelum dan setelah kemoterapi berdasarkan hasil pengukuran dengan kuesioner EORTC QLQ-C30 untuk kedua regimen. 
Setelah kemoterapi, pasien cenderung mengalami peningkatan fungsi fisik, meskipun yang bermakna hanya pada regimen PVB $(p=0,011)$. Hasil ini sejalan dengan pengamatan di RSUP Dr. Sardjito. Berdasarkan hasil penelitian tersebut diperoleh hasil bahwa setelah kemoterapi dengan regimen berbasis cisplatin, cenderung terjadi peningkatan fungsi fisik, meskipun tidak bermakna ${ }^{8}$. Hasil penelitian pada kombinasi carboplatin-paklitaksel di RS Sanglah Denpasar menunjukkan peningkatan fungsi fisik secara bermakna ${ }^{6}$.

Pemberian kemoterapi menimbulkan efek samping berupa kelelahan ${ }^{9}$ sehingga pasien tidak dapat melakukan aktivitas dalam menjalankan perannya. Berdasarkan hasil penelitian ini, terjadi peningkatan nilai fungsi peran meskipun hanya pada regimen PVB yang bermakna $(p=0,017)$. Peningkatan fungsi peran berkaitan dengan meningkatnya fungsi fisik dan kecenderungan menurunnya sebagian besar gejala setelah kemoterapi. Kedua hal tersebut menyebabkan pasien merasa lebih nyaman sehingga dapat kembali berperan, baik dalam kehidupan keluarga maupun di lingkungan tempat tinggalnya.

Sebelum menjalani kemoterapi, pasien merasakan khawatir, tegang dan depresi akibat penyakit yang dideritanya dan kemoterapi yang akan dijalani. Setelah kemoterapi, pasien secara psikologis berada dalam kondisi telah menerima keadaan bahwa dirinya menderita kanker dan menyadari bahwa kemoterapi memang dibutuhkan. Hal ini menyebabkan kondisi emosi menjadi lebih baik yang dinyatakan dengan peningkatan nilai domain emosi yang bermakna. Regimen PVB dan carboplatin-paklitaksel meningkatkan nilai fungsional emosi secara bermakna masing-masing dengan nilai $p=0,000$ dan $p=0,047$. Evaluasi pengaruh regimen cisplatin dan kombinasinya di RSUP Dr. Sardjito juga menunjukkan kecenderungan kenaikan fungsi emosi namun tidak bermakna8.

Kemoterapi dapat menurunkan fungsi kognitif akibat rasa cemas ${ }^{10}$ dan karena efek myelosupresi ${ }^{11}$. Berdasarkan penelitian ini teramati bahwa setelah kemoterapi, cenderung terjadi peningkatan fungsi kognitif pada kedua regimen dan bermakna pada regimen PVB $(p=0,011)$. Carboplatin menimbulkan myelosupresi yang lebih berat dibandingkan kemoterapi lain ${ }^{11}$. Meskipun efek samping myelosupresi dari carboplatin menyebabkan masalah pada kognitif, namun berdasarkan hasil penelitian ini, tidak terjadi penurunan. Hal ini karena kepada pasien diberikan vitamin B6. Vitamin B6 diperlukan pada proses pembentukan sel darah merah yang berfungsi menghantarkan oksigen termasuk ke sel-sel otak agar fungsi kognitif berjalan dengan baik ${ }^{12}$.

Pengaruh kemoterapi cenderung menurunkan nilai fungsi sosial karena pasien sedang menjalani perawatan dan harus menjalani istirahat total sehingga aktivitas sosial cenderung terganggu. Berdasarkan penelitian ini, tidak terjadi perubahan bermakna setelah mendapatkan kemoterapi dengan kedua regimen tersebut. Hasil ini sejalan dengan penelitian di India ${ }^{13}$.

Kelelahan adalah gejala umum yang dialami akibat pemberian kemoterapi karena efek samping myelosupresi yang menimbulkan anemia ${ }^{11}$. Kedua regimen menunjukkan kecenderungan penurunan gejala kelelahan setelah kemoterapi dan bermakna pada regimen PVB $(p=0,000)$. Penelitian di RSUP Dr. Sardjito pada regimen berbasis cisplatin juga menunjukkan terjadinya penurunan gejala kelelahan secara bermakna $^{8}$. Penurunan gejala diduga karena penanganan anemia dengan suplemen zat besi dan vitamin B kompleks atau transfusi darah. Selain itu pada penderita juga terjadi penurunan sebagian besar gejala sehingga gejala sulit tidur menjadi menurun yang berdampak menurunkan gejala kelelahan. Penurunan gejala ini juga teramati pada regimen carboplatin-paklitaksel meskipun tidak bermakna.

Kemoterapi menimbulkan efek samping mual dan muntah. Hal ini disebabkan oleh stimulasi pada reseptor di saluran cerna dan chemoreceptors trigger zone (CTZ) yang mengirim pesan ke nukleus 
traktur solitaries pada otak sehingga merangsang salivasi, kontraksi diafragma, otot pernafasan dan otot perut ${ }^{14}$. Pada penelitian ini, tidak terjadi perubahan bermakna pada gejala mual dan muntah meskipun menunjukkan kecenderungan peningkatan. Hal ini diduga disebabkan penggunaan antiemetik ondansetron. Berdasarkan hasil penelitian di India terbukti bahwa ondansetron menekan efek mual dan muntah yang merupakan efek samping cisplatin $^{15}$.

Nyeri tidak hanya disebabkan oleh kanker tapi juga merupakan efek samping kemoterapi ${ }^{16}$. Berdasarkan penelitian ini, terdapat kecenderungan penurunan nyeri setelah kemoterapi dan bermakna pada regimen PVB $(p=0,000)$. Hal ini sejalan dengan hasil penelitian pada regimen berbasis cisplatin di RSUP Dr. Sardjito ${ }^{8}$ dan regimen BOMP di RS Sanglah ${ }^{6,7}$. Penurunan gejala nyeri pada pasien diduga karena pemberian analgetik.

Obat kemoterapi, misalnya cisplatin, dapat menimbulkan gangguan pernafasan karena efek bronkokonstriksi sehingga menimbulkan sesak nafas ${ }^{17}$. Penanganan efek ini adalah dengan pemberian obat $\beta 2$ adrenergik seperti efinefrin atau dengan glukokortikoid $^{18}$. Pada kedua regimen ini, gejala tersebut cenderung menurun meskipun yang bermakna hanya pada regimen PVB $(p=0,003)$. Demikian pula pada penelitian di RSUP Dr. Sardjito, cenderung terjadi penurunan gejala sesak nafas meskipun tidak bermakna $^{8}$.

Nyeri karena kanker dan efek samping dari kemoterapi dapat menimbulkan gangguan tidur ${ }^{19}$. Berdasarkan hasil penelitian ini, setelah kemoterapi terjadi penurunan gejala sulit tidur baik pada regimen PVB $(p=0,000)$ maupun carboplatinpaklitaksel $(p=0,015)$. Hasil ini sejalan dengan penelitian di RS Sanglah pada regimen $\mathrm{BOMP}^{7}$ dan carboplatin-paklitaksel ${ }^{6}$.

Kemoterapi berefek neurologis yang berdampak pada terjadinya sembelit ${ }^{20}$ dan diatasi dengan pencahar seperti bisakodil. Hasil penelitian ini menunjukkan bahwa terjadi penurunan gejala sembelit yang bermakna pada regimen PVB $(p=0,001)$ dan carboplatin-paklitaksel $(p=0,024)$.

Kemoterapi menimbulkan ulser mukosa sehingga menyebabkan diare. Gejala ini diatasi dengan pemberian antidiare ${ }^{21}$. Setelah kemoterapi, terjadi kecenderungan penurunan gejala diare dan bermakna pada pasien dengan regimen PVB $(p=0,001)$. Hasil yang sejalan dengan penelitian ini adalah pada pengamatan di RSUP Dr. Sardjito. Pasien dengan regimen berbasis cisplatin mengalami penurunan gejala diare bermakna ${ }^{8}$.

Tingginya biaya terapi ${ }^{1}$ dapat meningkatkan kesulitan keuangan pada pasien. Hasil menunjukkan bahwa terjadi kecenderungan penurunan kesulitan keuangan setelah kemoterapi dan bermakna pada regimen carboplatin-paklitaksel $(p=0,031)$. Hal ini karena adanya jaminan kesehatan yang menanggung biaya pengobatan sehingga secara psikologis dapat meringankan beban keuangan. Hal ini juga teramati pada penelitian di RS Sanglah yaitu penurunan bermakna pada regimen carboplatin-paklitaksel6. Hasil yang berbeda terjadi pada penelitian di RSUP Dr. Sardjito. Berdasarkan hasil penelitian tersebut, terjadi peningkatan gejala keuangan bermakna pada regimen berbasis cisplatin ${ }^{8}$. Perbedaan ini diduga karena penelitian tersebut tidak dikhususkan pada pasien yang mendapatkan jaminan kesehatan.

Terjadi peningkatan bermakna pada domain status kesehatan / kualitas hidup global, baik pada regimen $\operatorname{PVB}(p=0,000)$ maupun carboplatin-paklitaksel $(p=0,025)$. Hal ini karena kecenderungan penurunan pada hampir semua gejala. Hasil ini sejalan dengan penelitian di RS Sanglah. Berdasarkan hasil penelitian tersebut, pada regimen BOMP terjadi kecenderungan peningkatan domain tersebut meskipun tidak bermakna7, sedangkan pada regimen carboplatinpaklitaksel terjadi peningkatan bermakna ${ }^{6}$.

Tabel 3 mencantumkan data selisih nilai domain untuk kedua regimen pada sebelum dan setelah kemoterapi. Uji statistik terhadap 
Tabel III. Selisih Domain Kualitas Hidup Sebelum dan Setelah Kemoterapi

\begin{tabular}{lccccc}
\hline \multirow{2}{*}{ Domain } & \multicolumn{4}{c}{ Regimen } \\
\cline { 2 - 4 } & \multicolumn{2}{c}{$\begin{array}{c}\text { Cisplatin-vinkristin- } \\
\text { bleomisin }\end{array}$} & $\begin{array}{c}\text { Carboplatin- } \\
\text { paklitaksel }\end{array}$ & p \\
\cline { 2 - 4 } & Rata-rata & SD & Rata-rata & SD & \\
\hline Fungsional & 13,33 & 21,14 & 12,39 & 39,49 & 0 \\
$\quad$ Fisik & 15,62 & 25,79 & 13,21 & 45,37 & 0,164 \\
$\quad$ Peran & 25,71 & 23,71 & 24,57 & 32,98 & 0,091 \\
Emosi & 10,00 & 19,05 & 13,97 & 30,76 & 0,077 \\
Kognitif & 5,71 & 15,63 & 12,69 & 29,92 & 0,278 \\
$\quad$ Sosial & & & & & \\
Gejala & $-20,63$ & 21,75 & $-9,15$ & 26,63 & 0,150 \\
$\quad$ Kelelahan & $-2,86$ & 32,21 & 5,34 & 41,85 & 0,272 \\
$\quad$ Mual dan Muntah & $-19,84$ & 24,38 & $-3,96$ & 27,20 & 0,328 \\
$\quad$ Nyeri & $-13,81$ & 25,72 & $-6,10$ & 15,41 & 0,410 \\
$\quad$ Sesak Nafas & $-20,00$ & 22,83 & $-17,85$ & 32,15 & 0,444 \\
$\quad$ Sulit Tidur & 14,76 & 28,80 & 8,10 & 25,38 & 0,151 \\
$\quad$ Penurunan Nafsu Makan & $-15,24$ & 21,23 & $-16,16$ & 25,99 & 0,162 \\
$\quad$ Sembelit & $-10,95$ & 20,98 & $-12,12$ & 25,92 & 0,353 \\
$\quad$ Diare & $-3,17$ & 16,95 & $-6,06$ & 10,38 & 0,281 \\
$\quad$ Kesulitan Keuangan & 37,14 & 18,34 & 28,51 & 32,99 & 0,411 \\
Status Kesehatan / Kualitas & & & & & \\
Hidup Global & & & & &
\end{tabular}

selisih nilai domain antar regimen menunjukkan bahwa tidak terdapat perbedaan bermakna. Hal ini berarti tidak terdapat perbedaan bermakna dari kedua regimen terhadap kualitas hidup pasien. Hasil tersebut sejalan dengan hasil penelitian di Austria22.

\section{KESIMPULAN}

Setelah kemoterapi selama tiga siklus, nilai domain baik pada pasien dengan regimen PVB maupun carboplatin-paklitaksel, terjadi kecenderungan peningkatan pada fungsional, penurunan pada gejala dan peningkatan pada status kesehatan/kualitas hidup global, kecuali pada gejala mual dan muntah serta penurunan nafsu makan yang menunjukkan kecenderungan peningkatan. Pada pasien dengan regimen PVB terjadi peningkatan bermakna $(p=0,009)$ pada penurunan nafsu makan. Tidak terdapat perbedaan bermakna pada kualitas hidup pasien dengan regimen PVB dibandingkan dengan regimen carboplatin-paklitaksel.

\section{DAFTAR PUSTAKA}

1. Ricciardi, A., Langeron, N., Rossi, P.G., Raffaele, M., Cohet, C., Federici, A., Palazzo, F Incidence of Invasive Cervical Costs Associated with Its Management in Italy, Tumori. 2009; ISSN: 0300-8916. 95: 146-152.

2. Perwitasari, D.A., Atthobari, J., Dwiprahasto, I., Hakimi, M., Gelderbion, H., Putter, H., Nortier, J.W.R., Guchelaar, H.J. and Kaptein, A.A. Translation and Validation of EORTC QLQ-C30 into Indonesian Version for cancer Patients in Indonesia. Jpn J Clin Oncol. 2011;41(4); 1-11.

3. Krikeli, M., Ekonomopoulou, M.T., Tzitzikas, I., Goutzioulis, A., Mystakidou, K., Gombaki, K.P., Comparison of The Impact of 
Radiotherapy and Radiochemotherapy on The Quality of Life of 1-year Survivors with Cervical Cancer, Cancer Manag Res. 2011;

4. Komite Nasional Penanganan Kanker (KPKN). Panduan Pelayanan Klinis Kanker Serviks, Jakarta: Kementerian Kesehatan Republik Indonesia; 2015.

5. National Comprehensive Cancer Network (NCCN) 2013. NCCN Clinical Practice Guidelines in Oncology Cervical Cancer version 2.2013.1-2. www.nccn.org. Dipublikasikan 2013. Diakses 25 November 2015.

6. Tunas, I.K., Yowani, S.C., Indrayathi, P.A., Noviani, R., Budiana, I.N.G., 2016, Penilaian Kualitas Hidup Pasien kanker Serviks dengan Kemoterapi PaklitakselCarboplatin di RSU Sanglah, ICJP, 2016; 5(1):35-46

7. Noviyani, R., Budiana, I.G.D., Indrayathi, P.A., Assessment of Life Quality of Cervical Cancer Patients Delivered Bleomycin-OncovinMitocyn-Platinum (BOMP) Chemotherapy Regimens in Sanglah Denpasar, IJBB, 2015; DOI: https://doi.org/10.15416/ijcp.2015.4.2.10 6. 2(2):54-62.

8. Perwitasari, D.A., Pengukuran Kualitas Hidup Pasien Kanker Sebelum dan Sesudah Kemoterapi dengan EORTC QLQ C-30 di RSUP Dr. Sardjito Yogyakarta, Indonesian J Pharm, 2009; ISSN: 0126-1037; 20(2):68-72.

9. Glaze, S., Lisa, T., Pamela, C., Prafull, G., Jill, N., Greg, N.. Dose-dense Paclitaxel with Carboplatin for Advanced Ovarian Cancer: a Feasible Treatment Alternative. JOGC,2013; 35(1):61-66

10. Setiawan, SD., The Effect of Chemotherapy in Cancer Patients to Anxiety, Majority, 2015; ISSN : 23373776. 4(4):94-99.

11. Schagen, S.B., dan Wefel, J.S., Chemotherapy-related Changes in Cognitive Functioning, EJC Supplements II, 2013;11(2): 225-232.
12. Lammers, Y., O' Rourke, B., Gilbert, R.L., Keeling C., Matthews, D.E., Stacpoole, P.W. and Gregory III, J.F., Vitamin B-6 Restriction tends to reduce the red blood cell glutathione synthesis rate without affecting red blood cell or plasma glutathione concentrations in healthy men and women, Am J Clin Nutr. 2009; 90:336-43.

13. Singh, H., Kaur, K., Banipal, R.P.S., Singh, S., Bala, R., 2014, Quality of Life in Cancer Patients Undergoing Chemotherapy in a Tertiary Care Center in Malwa Region of Punjab, Indian J Palliat Care. 2014; DOI: 10.4103/09731075.105683. 20(2):116-122.

14. Hawkins, R., Grunberg, S., Chemotherapy Induced Nausea and Vomiting: Challenges and Opportunities for Improved Patients Outcomes, CJON; e-ISSN: 1538-067X. 2009; 13(1):54-64.

15. Tonato, M. (Ed.), Antiemetics in The Supportive Care of Cancer Patients, Springer, Perugia; 2012

16. Park, H.J., Chemotherapy Induced Peripheral Neurophatic Pain, Korean J Anesthesiol. 2014; e-ISSN: 2005-7563. 67(1):4-7

17. Astolfi, L., Ghiselli, S., Guaran, V., Chicca, M., Simoni, E., Olivetto, E., Lelli, G. and Martini, E., Correlation of Adverse Effects of Cisplatin Administration in Patients Affected by Solid Tumours : A Retrospective Evaluation, Oncol Rep. 2013; 29:12851292

18. Nugroho, A.E., Farmakologi Obat-obat Penting dalam Pembelajaran Ilmu Farmasi dan Dunia Kesehatan, Pustaka Pelajar, Yogyakarta; 2013

19. Otte, J.L., Carpenter, J.S., Manchanda, S., Rand, K.L., Skaar, T.C., Weaver, M., Chernyak, Y., Zhong, X., Igega, C. And Landis, S., Systematic Review of Sleep Disorder in Cancer Patients : Can The Prevalence of Sleep Disorders be Ascertained?, Cancer Med; e-ISSN: 2015. 4(2): $183-200$ 
20. McQuade, R.M., Stojanovska, V., Abalo, R., Bornstein, J.C. and Nurgali, K., Chemotherapy-Induced Constipation and Diarrhea: Pathophysiology, Current and Emerging Treatments, Front Pharmacol. 2016; e-ISSN: 16639812. 7:1-9.

21. Stein, A., Voigt, W. and Jordan, K., Chemotherapy-Induced Diarrhea: Pathophysiology, Frequency and
Guideline-Based Management, Ther Adv Med Oncol. 2010; e-ISSN: 17588359. 2(1):51-63.

22. Greimel, E., Thiel, I., Peintinger, F., Cegnar, I., Pongratz, E, Prospective Assessment of Quality of Life of Female Cancer Patients, www.gynecologiconcology-online.net. Dipublikasikan 2014. Diakses 1 Desember 2016. 